\title{
E-VOTING DENGAN ELECTRONIC VOTING MACHINE DAN FINGERPRINT ONE- DETECT VERIFICATION SEBAGAI KATALISATOR MODERNISASI PEMILU DI INDONESIA
}

Teguh Cahya Yudiana, Cut Hasri Nabila, Billiam; Fakultas Hukum Universitas Padjadjaran, Jl. Raya Bandung Sumedang KM. 21 Jatinangor, Kabupaten Sumedang, Jawa Barat 45363;

E-mail: teguhcahyayudiana@gmail.com, cutnabila@gmail.com, billiam.setiawan@gmail.com

\begin{abstract}
Abstrak
Konstitusi Indonesia tidak mengatur secara jelas mengenai mekanisme pemungutan suara pada Pemilihan Umum (Pemilu). Hingga saat ini, Pemilu di Indonesia masih diselenggarakan dengan mekanisme konvensional (mencoblos atau mencontreng surat suara). Melalui metode penelitian yuridis normatif yang bersifat deskriptif terapan, diketahui bahwa mekanisme konvensional tersebut menimbulkan banyak permasalahan, seperti (1) beratnya beban kerja panitia ad hoc Pemilu; (2) mobilitas dan alokasi logistik yang rumit; (3) alokasi anggaran Pemilu Serentak Indonesia 2019 yang besar; dan (4) banyaknya surat suara tidak sah disebabkan tingkat pengetahuan masyarakat yang rendah. Sesuai Teori Hukum Progresif, hukum itu ada untuk manusia, sehingga permasalahan-permasalahan tersebut harus diatasi dengan mekanisme baru bagi penyelenggaraan Pemilu di Indonesia. Mekanisme tersebut adalah e-voting dengan Electronic Voting Machine (EVM) dan Fingerprint One-Detect Verification (FOV). Gagasan inovasi ini akan melengkapi EVM dengan kemampuan fingerprint one detect-verification yang secara bertahap akan diselenggarakan di Indonesia dengan tetap menjamin asas-asas Pemilu, diselenggarakan oleh Tim Khusus Revolusi E-voting yang dibentuk oleh Komisi Pemilihan Umum. E-voting dengan EVM dan FOV hadir sebagai solusi atas permasalahan yang ditimbulkan oleh mekanisme konvensional maupun kekurangan e-voting yang telah ada, sekaligus menjadi katalisator modernisasi pemilu di Indonesia.
\end{abstract}

Kata Kunci: Pemilihan Umum, Electronic Voting Machine (EVM), Fingerprint One-Detect Verification (FOV).

\begin{abstract}
The Indonesian constitution does not regulate the voting mechanism in the General Election (Pemilu). Until now, elections in Indonesia are still held using conventional mechanisms (checking the ballots). Through normative juridical research methods that are descriptive in nature, it is known that the conventional mechanism causes many problems, such as (1) the heavy workload of the ad hoc election committee; (2) complex logistics allocation and mobility; (3) the large 2019 Indonesian Simultaneous Election budget allocation; and (4) the number of invalid ballots due to the low level of public knowledge. According to Progressive Legal Theory, the law exists for humans, so these problems must be overcome with a new mechanism for the implementation of elections in Indonesia. The mechanism is e-voting with an Electronic Voting Machine (EVM) and Fingerprint One-Detect Verification (FOV). This innovative idea will complement EVM with fingerprint one detect-verification capabilities which will gradually be held in Indonesia while still ensuring the principles of the General Election, organized by the Special Team for the Evoting Revolution formed by the General Elections Commission. E-voting with EVM and FOV is present as a solution to the problems caused by conventional mechanisms and the lack of existing e-voting, as well as being a catalyst for the modernization of elections in Indonesia.
\end{abstract}

Keywords: General Election, Electronic Voting Machine (EVM), Fingerprint One-Detect Verification (FOV)

\section{PENDAHULUAN}

\section{Latar Belakang}

Praktik electronik voting (e-voting) di Indonesia sebenarnya telah dilakukan pada tingkat lokal, yakni di Kabupaten Jembrana, Bali yang telah menerapkannya di tingkat 
Pemilihan Kepala Desa (Pilkades) sejak tahun 2008. ${ }^{1}$ E-voting sendiri merupakan suatu proses pemilihan yang mencakup proses pemungutan dan penghitungan suara dengan menggunakan perangkat elektronik. ${ }^{2}$ Setelah berhasil melaksanakan e-voting, Pemerintah Kabupaten Jembrana menyatakan bahwa e-voting lebih menjamin penyelenggaraan Pemilihan Umum (Pemilu) dan Pemilihan Kepala Daerah (Pilkada) dengan asas-asasnya serta relatif lebih murah dibandingkan dengan penggunaan mekanisme konvensional. Pemerintah Kab. Jembrana selaku Pemohon mengajukan uji materi (judicial review) ke Mahkamah Konstitusi (MK) dengan tujuan memohonkan adanya suatu payung hukum untuk penggunaan e-voting. Melalui Putusan MK Nomor 147/PUU-VII/2009, MK mengabulkan permohonan para Pemohon untuk sebagian dan terhadap Pasal 88 Undang-Undang Nomor 32 Tahun 2004 tentang Pemerintahan Daerah diartikan konstitusional bersyarat oleh MK sepanjang metode e-voting yang digunakan sesuai dengan syarat kumulatif, yaitu (1) tidak melanggar asas langsung, umum, bebas, rahasia, jujur, dan adil (Luber Jurdil); dan (2) daerah yang menerapkan metode e-voting sudah siap baik dari sisi teknologi, pembiayaan, sumber daya manusia, maupun perangkat lunaknya, kesiapan masyarakat di daerah yang bersangkutan, serta persyaratan lain yang diperlukan. ${ }^{3}$

Namun, hingga saat ini, pelaksanaan pemungutan suara pada Pemilu di Indonesia umumnya masih dilakukan dengan mekanisme konvensional, yakni dengan menggunakan paku untuk mencoblos kertas suara atau mencontreng kertas suara. Pengaturan mengenai pemilu di konstitusi sendiri termaktub pada Pasal 22E ayat (1) Undang-Undang Dasar Negara Republik Indonesia Tahun 1945 (UUD NRI 1945) yang menyebutkan bahwa, "Pemilihan umum dilaksanakan secara langsung, umum, bebas, rahasia, jujur dan adil setiap lima tahun sekali". ${ }^{4}$ Berdasarkan ketentuan tersebut, dapat dilihat bahwa UUD NRI 1945 sendiri tidak mengatur secara spesifik mengenai pemilu maupun mekanisme pemungutan suara dalam pemilu. Konstitusi yang tidak memuat suatu aturan yang spesifik dan eksplisit mengenai suatu dasar konstitusional kebijakan publik memberi dasar bagi pilihan kebijakan hukum yang terbuka (open legal policy) yang menjadi dasar kewenangan bagi pembuat undang-undang untuk menjelaskannya lebih jauh dalam suatu undang-undang sebagai pengaturan lebih lanjut. ${ }^{5}$

Lantas, yang menjadi pertanyaan adalah mengapa MK mengabulkan permohonan tersebut? Ternyata, pelaksanaan Pemilu serentak dengan mekanisme konvensional pada tahun 2019 menimbulkan banyak permasalahan. Salah satunya adalah dengan adanya 894 orang panitia ad hoc yang meninggal dunia dan 11.239 orang yang jatuh sakit dikarenakan mengalami kelelahan dalam memantau dan membantu berjalannya proses

\footnotetext{
${ }^{1}$ Habibi, Muhammad dan Nurmandi, Achmad. (2019). “Dinamika Implementasi E-Voting di Berbagai Negara", Jurnal UMY, 7(2), 4.

2 Mote, C.D. (2001). "Report of the National Workshop on Internet Voting - Issues and Research Agenda". Internet Policy Institute, $h .14$.

3 Lihat Putusan Mahkamah Konstitusi Nomor 147/PUU-VII/2009, h. 41-42.

${ }^{4}$ Pasal 22E ayat (1) Undang-Undang Dasar Negara Republik Indonesia Tahun 1945.

5 Satriawan, Iwan dan Lailam, Tanto. (2019). “Open Legal Policy dalam Putusan Mahkamah Konstitusi dan Pembentukan Undang-Undang". Jurnal Konstitusi, 16 (3), 564.
} 
pemungutan suara di setiap wilayah di Indonesia. ${ }^{6}$ Selain memberikan beban kerja yang berat kepada panitia ad hoc, mekanisme konvensional dalam Pemilu Serentak Indonesia 2019 juga mengakibatkan timbulnya masalah mobilitas dan alokasi yang rumit. Hal ini dibuktikan dengan adanya 10.520 TPS yang mengalami kekurangan logistik termasuk didalamnya kotak suara dan alat bantu tuna netra pada Pemilu Serentak Indonesia 2019.7 Akhirnya, permasalahan tersebut menyebabkan terganggunya proses pemungutan suara pada pemilu di daerah-daerah tersebut. Selain kedua masalah di atas, terdapat juga permasalahan-permasalahan lainnya yang disebabkan oleh mekanisme konvensional dalam Pemilu Serentak Indonesia 2019, seperti alokasi anggaran yang relatif besar dan banyaknya surat suara tidak sah yang disebabkan tingkat pengetahuan masyarakat yang rendah.

Permasalahan-permasalahan ini tentu perlu direspon dalam wilayah hukum, mengingat hukum harus bergerak dinamis seiring dengan perkembangan masyarakat. Pemahaman ini sejalan dengan Teori Hukum Progresif yang dikemukakan oleh Satjipto Rahardjo yang menyatakan bahwa hukum ada untuk manusia, untuk membahagiakan manusia, dan untuk kepentingan manusia, bukan manusia untuk hukum. ${ }^{8}$ Oleh karena itu, sudah sepantasnya hukum yang ada mampu mengatasi permasalahan-permasalahan yang disebabkan oleh mekanisme konvensional tersebut melalui keberadaan payung hukum bagi mekanisme e-voting.

Mekanisme e-voting tentunya akan meringankan beban kerja panitia ad hoc, mempermudah mobilisasi dan alokasi logistik pemilu, menekan anggaran yang dikeluarkan, hingga meminimalisir surat suara tidak sah yang disebabkan tingkat pengetahuan masyarakat yang rendah. Namun, mekanisme ini tetap memiliki kekurangan, yakni adanya kemungkinan error atau hack yang mengganggu kredibilitas dalam pemilu, permasalahan operasional dan logistik, dan modal atau biaya awal serta biaya perawatan mesin yang cukup mahal.

Berdasarkan hal tersebut, mengingat pemilu-pemilu selanjutnya yang kemungkinan besar akan dilaksanakan secara serentak, maka mekanisme e-voting menjadi mekanisme yang penulis tawarkan untuk tidak mengulangi kesalahan yang sama pada pemilu serentak selanjutnya. Mekanisme e-voting dengan Electronic Voting Machine (EVM) dan Fingerprint One-Detect Verification (FOV) hadir sebagai solusi yang penulis yakini dapat menyelesaikan permasalahan yang ditimbulkan oleh pelaksanaan pemilu dengan mekanisme konvensional maupun mekanisme e-voting yang telah ada sekaligus sebagai katalisator modernisasi pemilu di Indonesia.

6 Sania Mashahi, "Refleksi Pemilu 2019, Sebanyak 894 Petugas KPPS Meninggal Dunia", Kompas.com, berita dari https://nasional.kompas.com/read/2020/01/22/15460191/refleksipemilu-2019-sebanyak-894-petugas-kpps-meninggaldunia, diakses pada tanggal 11 Maret 2021.

7 Afrimadona, Amir Nashirudin, dkk, 2019, Perihal Pemungutan dan Penghitungan Suara, cet. ke1, Jakarta: BAWASLU, h. 116.

${ }^{8}$ Rahardjo, Satjipto. (2006). Membedah Hukum Progresif. Jakarta: Kompas, h. 188. 


\section{Rumusan Masalah}

Berdasarkan latar belakang di atas, rumusan masalah dalam penelitian ini adalah sebagai berikut:

1. Bagaimanakah evaluasi permasalahan Pemilu Serentak Indonesia 2019 dengan penggunaan mekanisme konvensional?

2. Bagaimanakah mekanisme e-voting dengan Electronic Voting Machine (EVM) dan Fingerprint One-Detect Verification (FOV) dalam pelaksanaan Pemilu Indonesia?

3. Bagaimanakah perbandingan mekanisme konvensional dengan mekanisme e-voting dengan Electronic Voting Machine (EVM) dan Fingerprint One-Detect Verification (FOV) ditinjau dari pendekatan teoritis sebagai perwujudan optimalisasi pembangunan hukum?

\section{METODE PENELITIAN}

Penelitian ini menggunakan metode penelitian yuridis normatif dengan sifat pengumpulan teknik library research, berbentuk penelitian deskriptif terapan (applied research), dimana pengaplikasian terhadap inovasi yang penulis temukan akan dikaitkan dengan konsep teori dan kaidah hukum tertentu. Dengan saran dan hasil dari penelitian dalam karya ilmiah ini, penulis harapkan dapat menunjang kegiatan pembangunan hukum yang sedang berjalan terkhususnya dalam topik yang penulis pilih.

\section{PEMBAHASAN}

\section{A. Evaluasi Permasalahan Pemilu Serentak Indonesia 2019 dengan Penggunaan Mekanisme Konvensional}

\section{Beratnya Beban Kerja Panitia Ad Hoc Pemilu}

Pemilu Serentak Indonesia 2019 yang diselenggarakan pada tanggal 17 April 2019, ternyata mengungkapkan fakta bahwa panitia ad hoc yang ditugaskan untuk memantau dan membantu berjalannya proses pemungutan suara di setiap wilayah di Indonesia, banyak yang mengalami kelelahan hingga jatuh sakit bahkan meninggal dunia. Jumlah keseluruhan panitia ad hoc yang meninggal dunia diperkirakan mencapai sebanyak 894 orang, yang mana jumlah ini belum termasuk panitia yang sakit sebanyak 11.239 orang. ${ }^{9}$ Salah satu faktor penyebabnya adalah penugasan yang menyatakan bahwa penghitungan suara dilaksanakan pada pukul 13.00 waktu setempat setelah selesainya pelaksanaan pemungutan suara. ${ }^{10}$ Dalam hal tertentu yang menyebabkan diperlukannya penghitungan ulang surat suara di TPS atau PPK, panitia ad hoc diharuskan untuk menyelesaikan hasil rekapitulasi

\footnotetext{
9 Sania Mashahi, "Refleksi Pemilu 2019, Sebanyak 894 Petugas KPPS Meninggal Dunia", Kompas.com, berita dari https://nasional.kompas.com/read/2020/01/22/15460191/refleksipemilu-2019-sebanyak-894-petugas-kpps-meninggal-dunia, diakses pada tanggal 11 Maret 2021. ${ }^{10}$ Lihat rumusan Pasal 4 ayat (1) dan (2) Peraturan KPU Nomor 8 Tahun 2018 tentang Pemungutan dan Penghitungan Suara Pemilihan Gubernur dan Wakil Gubernur, Bupati dan Wakil Bupati, dan/atau Wali Kota dan Wakil Wali Kota.
} 
suara dengan tepat waktu agar dapat diakumulasikan dengan total perolehan dari wilayah Indonesia lainnya kepada pihak KPU.11

Perwujudan hak politik yang sejatinya harus ditegakkan dengan bantuan penyelenggara pemilu, a contrario justru mengakibatkan hak asasi yang melekat pada tiap-tiap orang yang terlibat didalamnya terkhususnya hak hidup, ${ }^{12}$ juga ikut terancam. Oleh sebab itu, bentuk pemenuhan terhadap hak hidup setiap warga negara harus dijunjung tinggi oleh negaranya sebagai pihak yang bertanggung jawab untuk memastikan hak tersebut tetap terjaga (state responsibility).

Menyikapi peristiwa tersebut, KPU memberikan santunan sebagai bentuk tindak lanjut dari musibah ataupun kerugian yang dialami oleh panitia ad hoc selama menjalankan tugasnya. ${ }^{13}$ Nantinya korban atau keluarga korban harus memenuhi empat tahapan yang dimulai melalui pendataan; identifikasi; verifikasi; dan pengeluaran surat keputusan Sekretaris Jenderal untuk pencairan santunan. ${ }^{14}$ Mengutip pada Laporan KPU Kabupaten Sleman, masih banyak pula korban yang tidak mendapatkan dana santunan dikarenakan kelengkapan persyaratan yang kurang; tidak termasuk ke dalam kriteria korban yang mendapatkan santunan; ataupun kurang jelasnya alur penyampaian data kepada KPU kabupaten/kota sehingga menyebabkan banyak data yang invalid. ${ }^{15}$

Realisasi Pemilu Serentak Indonesia 2019, dimana aturan beban kerja yang sangat memberatkan para panitia ad hoc dengan waktu terbatas, risiko yang tinggi, dan juga jumlah anggota yang telah ditentukan oleh undang-undang, tidaklah dapat dipungkiri lagi. Pencapaian yang ingin diwujudkan dengan pemilu serentak sejatinya adalah sia-sia apabila justru harus mengorbankan pihak-pihak didalamnya hanya dikarenakan tidak efisiennya suatu mekanisme.

Perlu digaris bawahi bahwa kejadian tersebut berlangsung sebelum Indonesia tercemari dengan pandemi Coronavirus Disease (COVID-19), sehingga dapat dibayangkan apabila penggunaan mekanisme konvensional tetap berlanjut di tengah situasi genting pandemi saat ini. Urgensi perubahan wujud dari mekanisme konvensional ke bentuk pembaharuan modernisasi e-voting pun diperlukan agar pemilu kedepannya tidak terulang lagi dengan kegagalan yang memakan banyak korban jiwa.

\footnotetext{
${ }^{11}$ Lihat rumusan Pasal 67 ayat (5) Peraturan KPU Nomor 8 Tahun 2018 tentang Pemungutan dan Penghitungan Suara Pemilihan Gubernur dan Wakil Gubernur, Bupati dan Wakil Bupati, dan/atau Wali Kota dan Wakil Wali Kota.

${ }^{12}$ Lihat rumusan Pasal 28 A Undang-Undang Dasar Negara Republik Indonesia Tahun 1945.

${ }^{13}$ Lihat rumusan Bab IV Surat Keputusan Nomor: 926/KU.03.2-Kpt/O5/KPU/IV/2019 tentang Pedoman Teknis Pemberian Santunan Kecelakaan Kerja Bagi Anggota dan Sekretariat Panitia Pemilihan Kecamatan dan Panitia Pemungutan Suara, Anggota Kelompok Penyelenggara Pemungutan Suara, dan Petugas Ketertiban Tempat Pemungutan Suara Dalam Penyelenggaraan Pemilihan Umum Tahun 2019.

14 Ibid.

${ }^{15 K P U ~ K a b . ~ S l e m a n . ~(2019) . ~ L a p o r a n ~ P e m b e n t u k a n ~ B a d a n ~ P e n y e l e n g g a r a ~ A d ~ H o c ~ P e m i l u ~} 2019$ Kabupaten Sleman. Sleman: KPU, h. 53.
} 


\section{Mobilitas dan Alokasi Logistik Pemilu Konvensional yang Rumit}

Indonesia sebagai negara kepulauan, yang mencakup daerah 3T, nyatanya berpotensi menimbulkan persoalan dalam pengalokasian logistik perlengkapan pemilu. Hal ini dibuktikan pada saat Pemilu Serentak Indonesia 2019, terdapat 10.520 TPS yang kekurangan logistik termasuk kotak suara dan alat bantu tunanetra. ${ }^{16}$ Seperti yang dilansir pada data Bawaslu, ditemukan keterlambatan pengiriman distribusi logistik pada sebanyak 12 kecamatan di Kabupaten Banggai, dikarenakan pemenuhan kebutuhan sesuai dengan permintaan dari KPU pusat cukup lambat direspons oleh pihak daerah. ${ }^{17}$ Tak hanya di Provinsi Sulawesi Tengah, wilayah lain terkhususnya yang berada pada daerah 3T seperti Jayapura dan Manokwari, juga mengalami keterlambatan mobilisasi logistik sehingga terdapat beberapa warga yang tidak dapat menyalurkan hak suaranya, ${ }^{18}$ kendati pemilu serentak telah diberlangsungkan sejak pukul 07.00 sampai pukul 13.00 waktu setempat. ${ }^{19}$

Persoalan wilayah juga bukan menjadi satu-satunya penyebab kesulitan dalam mobilisasi dan alokasi logistik yang rumit. Hal ini juga semakin dipersulit sebagai konsekuensi hukum dari Putusan MK Nomor 20/PUU-XVII/2019. Putusan MK ini mensyaratkan KPU harus kembali mendata pemilih yang belum terdaftar di Daftar Pemilih Tetap (DPT) dengan melampirkan KTP elektronik (e-KTP) atau surat keterangan perekaman e-KTP. Tak hanya itu, KPU juga diwajibkan untuk mendata pemilih pindahan yang masuk Daftar Pemilih Tetap Tambahan (DPTb) sampai 7 hari sebelum waktu penyelenggaraan pemilu. ${ }^{20}$ Akibatnya, pendataan DPT dan DPTb yang terlambat ini akan berpengaruh pada jumlah surat suara yang harus dicetak oleh KPU. Sehingga, pada saat hari pelaksanaan masih banyak surat suara, kotak suara, bilik suara, dan logistik lainnya yang cacat dan memerlukan perbaikan. Penyaluran dan mobilisasi logistik yang tingkat penyebarannya masih terbilang jauh dari rata pada wilayah Indonesia, memang disebabkan oleh berbagai aspek. Namun, percepatan dan peran adaptif yang tinggi oleh pemerintah sangat dibutuhkan dalam perwujudan pemilu kedepannya, agar permasalahan logistik tidak lagi menjadi penyebab Warga Negara Indonesia (WNI) terhalang untuk menyalurkan aspirasi suaranya.

\footnotetext{
${ }^{16}$ Afrimadona, Amir Nashirudin, dkk. (2019). Perihal Pemungutan dan Penghitungan Suara, Cet. ke1, Jakarta: BAWASLU, h. 116.

17 Ranap Tumpal HS, "Bawaslu Temukan Logistik Pemilu di Sulteng Terlambat", Bawaslu, berita dari https://bawaslu.go.id/id/berita/bawaslu-temukan-logistik-pemilu-di-sulteng-terlambat, diakses pada 16 Maret 2021.

18 Luthfia Ayu Azanelia, "Pencoblosan, Ini Masalah Logistik Pemilu yang Masih Banyak Ditemukan", Kompas.com, berita dari https://regional.kompas.com/read/2019/04/17/13124121/pencoblosan-ini-masalah-logistikpemilu-yang-masih-banyak-ditemukan?page=all, diakses pada 16 Maret 2021.

${ }_{19}$ Lihat rumusan Pasal 8 ayat (14) PKPU Nomor 9 Tahun 2019 tentang Perubahan Atas PKPU Nomor 3 Tahun 2019 tentang Pemungutan dan Penghitungan Suara dalam Pemilihan Umum.

${ }^{20}$ Fadli Ramadhanil, Heroik M, dkk, Op. Cit., h. 81.
} 


\section{Alokasi Anggaran Pemilu Serentak Indonesia 2019 yang Relatif Besar}

Data KPU pada Pemilu Serentak Indonesia 2019 menunjukkan bahwa jumlah panitia pemilu di seluruh Indonesia berjumlah 7.671 .717 orang dengan alokasi anggaran sebesar Rp. 10.047.105.276.000 bagi pembentukan Pergantian Antar Waktu (PAW), honorarium dan belanja barang bagi penyelenggara pemilu, panitia ad hoc (PPK, PPS, dan KPPS). ${ }^{21}$ Apabila ditotalkan dengan keperluan pemilu lainnya, pemerintah telah menyiapkan anggaran sebesar Rp. 25.590.000.000.000.22 Untuk melihat alokasi kebutuhan Pemilu Serentak Indonesia 2019 pada aspekaspek pemilu yang difokuskan oleh pemerintah, dapat dilihat perbandingannya dengan alokasi anggaran pada Pemilu Indonesia 2014 pada tabel berikut:

Tabel 2: Alokasi Anggaran pada Pemilu Indonesia ${ }^{23}$

\begin{tabular}{|c|l|c|c|}
\hline No & \multicolumn{1}{|c|}{ Alokasi Anggaran } & Pemilu 2014 & Pemilu 2019 \\
\hline 1 & Pelaksanaan oleh KPU & Rp. 12,9 T & Rp. 15,93 T \\
\hline 2 & Pengawasan oleh Bawaslu & Rp. 3,7 T & Rp. 4,86 T \\
\hline 3 & $\begin{array}{l}\text { Pengamanan oleh Polri, Kemenkumham, } \\
\text { BIN, dan Menko Polhukam }\end{array}$ & Rp. 1,89 T & Rp. 3,11 T \\
\hline 4 & Sosialisasi oleh Kemkominfo, TVRI dan RRI & - & Rp. 0,16 T \\
\hline 5 & Penanganan Perselisihan oleh MK & Rp. 0,03 T & Rp. 0,24 T \\
\hline 6 & Audit oleh BPKP & - & Rp. 0,01 T \\
\hline 7 & $\begin{array}{l}\text { Sidang tahunan, pelantikan, dan akomodasi } \\
\text { oleh MPR, DPR, DPD, dan Setneg }\end{array}$ & Rp. 0,42 T & Rp. 0,51 T \\
\hline \multicolumn{2}{|c|}{ Total } & Rp. 18,94 T & Rp. 25,59 T \\
\hline
\end{tabular}

Alokasi anggaran ini merupakan pengeluaran terbesar selama penyelenggaraan pemilu di Indonesia. ${ }^{24}$ Pengeluaran anggaran dengan sedemikian banyaknya sepatutnya harus dipertimbangkan kembali, terlebih pelaksanaan pemilu serentak itu sendiri yang masih menimbulkan banyak permasalahan. Sejauh hasil dan pengeluaran biaya yang dikucurkan oleh pemerintah seimbang dan tidak timpang sebelah, maka anggaran dana dengan skala besar tersebut sangat dimungkinkan akan membawa dampak positif apabila dikelola secara patut dan benar.

\footnotetext{
${ }^{21}$ Yunita Amalia, "KPU Ungkap Honor Panitia Jadi Alokasi Terbesar Anggaran Pemilu 2019", merdeka.com, berita dari https://www.merdeka.com/peristiwa/kpu-ungkap-honor-panitia-jadialokasi-terbesar-anggaran-Pemilu-2019.html, diakses pada tanggal 07 Maret 2021.

${ }^{22}$ Rosadi, Farida., Reni Saptati, dkk. (2019). Media Keuangan: Transparansi Informasi Kebijakan Fiskal, Vol. XIV/No.139/April 2019. Jakarta: Sekretariat Jenderal Kementerian Keuangan, h. 5.

${ }^{23}$ Ringkang Gumiwang, "Alibi di Balik Lonjakan Anggaran Pemilu 2019: Dana BIN Hingga Hoax", Tirto.id, berita dari https://tirto.id/alibi-di-balik-lonjakan-anggaran-pemilu-2019-danabin-hingga-hoax-cUHz, diakses pada 16 Maret 2021.

${ }^{24}$ Rosadi, Farida., Reni Saptati, dkk. Op. Cit., h. 21.
} 


\section{B. E-Voting dengan Electronic Voting Machine (EVM) dan Fingerprint One-Detect Verification (FOV) dalam Pelaksanaan Pemilu Indonesia}

1. Teknologi Electronic Voting Machine (EVM)

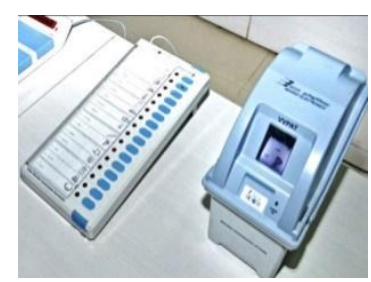

Gambar 2: Electronic Voting Machine (EVM) Generasi 325

Electronic Voting Machine (EVM) merupakan mesin atau unit komputer sederhana yang merekam pilihan pemilih tanpa menggunakan kertas. ${ }^{26}$ India merupakan negara yang telah menggunakan mesin EVM dengan menempatkan EVM di setiap Tempat Pemungutan Suara (TPS) dimana pemilu diselenggarakan. EVM merupakan pilihan yang lebih baik dibandingkan dengan mekanisme konvensional maupun mekanisme $e$-voting lainnya, dikarenakan (1) biaya yang relatif murah (sekitar \$200 atau Rp. 2.800.000); (2) sederhana dan mudah menggunakan; (3) bekerja dengan baterai (tidak menemui kendala soal listrik); (4) dapat menampung banyak pemilih; dan (5) dapat digunakan kembali dengan pengaturan yang mudah. ${ }^{27}$ Namun, terdapat permasalahan jika EVM yang diberlakukan di India diterapkan di Indonesia, yaitu mengenai kredibilitasnya karena EVM tidak memiliki verifikasi pemilih yang jelas dan masih dilakukan secara manual, yaitu peluang multivoting karena tidak ada verifikasi yang jelas menjamin satu kali pemilihan. Oleh karena itu, sebagai jawaban dari kekurangan mekanisme ini, penulis menggagas untuk memberlakukan EVM yang disempurnakan dengan Fingerprint One-Detect Verification (FOV) akan meningkatkan keamanan dalam hal verifikasi pemilih serta perbaikan sistem pemilihannya.

2. Inovasi E-Voting dengan Electronic Voting Machine (EVM) dan Fingerprint OneDetect Verification (FOV) dalam Pelaksanaan Pemilu Indonesia

FOV merupakan alat sensor sidik jari untuk verifikasi dalam mekanisme EVM yang diintegrasikan dengan perangkat lunak dengan database e-KTP yang sudah mengakomodir sidik jari pemilih. FOV merupakan tahap awal atau verifikasi sebelum memilih, yang dilengkapi kemampuan one-detect verification yang menyebabkan pemilih yang hanya dapat sekali memilih. FOV dilengkapi dengan papan ketik numerik bila terjadi kekeliruan atau pemilih belum memiliki

${ }^{25}$ ECI, "ECI Voting Equipments", ECI, berita dari https://eci.gov.in/evm/, diakses pada tanggal 1 Maret 2021.

${ }^{26}$ Muhammad Habibi, Achmad Nurmandi, Op. Cit., h. 10.

27 Reddy, A.K. (2011). "A Case Study On Indian E.V.M.S Using Biometrics". International Journal of Engineering Science \& Advanced Technology, 1(1), 40-42. 
e-KTP maka bisa menuliskan Nomor Induk Kependudukan (NIK) untuk alternatif.

Setelah verifikasi, pemilih memilih pilihan nya dengan cara mengetikan kode atau angka yang menjadi pilihannya, kemudian secara otomatis terekam dan terhitung ke pusat. EVM dan FOV ini dilengkapi suara dan lampu LED sebagai tanda keberhasilan verifikasi (hijau verifikasi berhasil, merah verifikasi gagal). Setelah memilih bukti telah memilih berupa kertas yang dicetak ( $Q R$ code) akan keluar melalui Voter Verified Paper Audit (VVPAT) yang nantinya dapat dibuka ketika ada persengketaan.

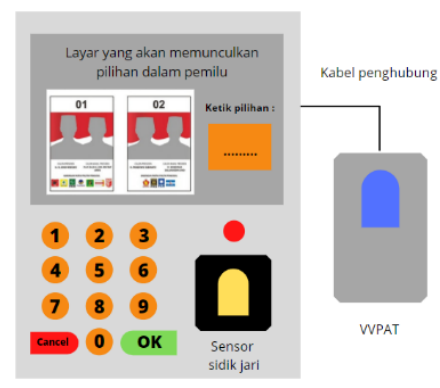

Gambar 3: Grand Design EVM dan FOV

\section{Potensi Permasalahan dan Solusi Penanganannya}

Mekanisme ini memiliki banyak keuntungan dan dapat menjadi solusi atas permasalahan pemilu yang terjadi dan berulang di Indonesia serta menyempurnakan kekurangan dari mekanisme e-voting pada umumnya. Namun, penggunaan mekanisme ini masih menimbulkan permasalahan dan hambatan, diantaranya adalah:

a. Potensi Permasalahan Perlindungan Data Pribadi, Praktik Hack, dan Kecurangan.

1) Potensi Permasalahan Perlindungan Data Pribadi

Potensi permasalahan mengenai data pribadi sangat dimungkinkan terjadi, mengingat mekanisme e-voting dengan EVM dan FOV menggunakan ruang siber atau cyberspace dan melibatkan data pribadi pemilih berupa data yang ada di e-KTP (nama, NIK, dan data pribadi lainnya dalam e-KTP).

Berdasarkan Rancangan Undang-Undang Perlindungan Data Pribadi (RUU PDP), dalam mekanisme ini KPU sebagai penyelenggara pemilu merupakan penyelenggara data pribadi dalam pelaksanaan e-voting dengan mekanisme EVM dan FOV yang bertanggung jawab atas perlindungan data pribadi pemilih. ${ }^{28}$ Kemudian, komisi khusus akan memastikan bahwa penyelenggara data pribadi tunduk dan patuh terhadap ketentuan di dalam RUU PDP. ${ }^{29}$

2) Mengadopsi perangkat lunak dan sistem keamanan e-voting dengan EVM di India 
EVM generasi pertama didasarkan pada model mesin Hitachi 6305 mikrokontroler dan menggunakan firmware (perangkat lunak permanen yang diprogram pada memory read only) di PROMs eksternal UV yang tak bisa terhapus bersamaan dengan 64kb EEPROMs di mesinnya. ${ }^{30}$ Kemudian sampai saat ini EVM yang digunakan India telah melakukan perbaikan dari evaluasi hingga generasi ketiga. Kemudian sejak tahun 2014. ${ }^{31}$

Maka dari itu, pemilu dengan e-voting menggunakan mesin EVM dan FOV yang digagas penulis bisa mengadopsi sistem keamanan dengan menggunakan minimal perangkat lunak dan sistem keamanan yang setara dengan yang diterapkan dalam mesin EVM di India. Dengan demikian, potensi hack dalam mekanisme ini dapat diminimalisir.

3) Mengadopsi sistem keamanan e-voting di Brazil

KPU Brazil mengemukakan bahwa mekanisme e-voting berhasil mencapai '100 \% bebas penipuan' yang berbeda dengan sistem pemilihan sebelumnya yaitu adanya indikasi surat suara yang rusak, penggandaan surat suara, penghilangan surat dan kotak suara hingga penggelembungan jumlah suara. ${ }^{32}$ E-voting di Brazil menggunakan sistem controlling, yaitu ketika pemilihan berlangsung KPU Brazil menyiapkan Ahli TI dan Tim Cyber Security untuk terus mengontrol proses transfer data untuk mengawasi dan mencegah adanya praktik hack serta kecurangan dalam pemilu.

Kelebihan dari sistem keamanan tersebut dapat diadopsi oleh Indonesia dalam e-voting dengan mekanisme EVM dan FOV yang penulis gagas untuk melakukan pengawasan dalam ruang siber dengan tim keamanan khusus. Selain itu, potensi permasalahan kecurangan pun dapat diminimalisir dengan diterapkannya pengawasan secara ketat oleh panitia atau admin di TPS.

b. Permasalahan Error System

Mengenai permasalahan error atau gangguan tentu saja sangat dimungkinkan, mengingat mekanisme yang penulis gagas merupakan mekanisme baru yang akan diterapkan secara luas. Sebagai langkah antisipasi, sebagaimana dijelaskan sebelumnya, penulis telah mendesain FOV sebagai langkah verifikasi yang dilengkapi dengan papan numerik sehingga ketika sensor sidik jari tidak terdeteksi/error (atau belum terintegrasi dengan e-KTP) maka dapat diverifikasi dengan menginput NIK pemilih.

Selain itu, ahli TI atau teknisi yang bertugas di masing-masing TPS akan terlebih dahulu mendapatkan pelatihan serta dipastikan memahami masalah teknis dalam mekanisme ini, sehingga permasalahan kemungkinan error dapat diatasi.

c. Permasalahan Internet

\footnotetext{
${ }^{30}$ Habibi, Muhammad dan Nurmandi, Achmad. Op. Cit., h. 12.

${ }^{31}$ Reddy, A.K., Loc. Cit.

32 Blanc, Jarrett. (2007). Challenging the Norms and Standards of Election Administration. USAID (h. 13). IFES.
} 
Mengenai kekhawatiran internet yang masih belum tersebar di seluruh daerah di Indonesia, hal ini terjawab dengan dukungan teknologi yang semakin berkembang. Kemkominfo menyatakan bahwa persebaran internet Indonesia pada tahun 2019-2020 mencapai 73,7\%, hal ini mengalami kenaikan 8,9\% persen dari tahun 2018.33 Jika melihat data tersebut, dapat disimpulkan persebaran internet secara keseluruhan di Indonesia akan tercapai sekitar tahun 2025.

Hal ini didukung dengan adanya program Palapa Ring oleh Kemkominfo mengenai pembangunan 4 satelit yakni Palapa Ring Barat, Palapa Ring Tengah, Palapa Ring Timur, dan Satelit Multifungsi yang saat ini sedang berjalan, ${ }^{34}$ sehingga dimungkinkan untuk menunjang persebaran internet untuk mekanisme ini.

Kemudian, permasalahan gangguan jaringan internet dalam pelaksanaannya sangatlah dimungkinkan. Sebagai antisipasi, penulis menganjurkan pemerintah untuk menyediakan cadangan kuota data internet untuk antisipasi ketika terjadi gangguan internet.

Dengan demikian, potensi permasalahan yang dimungkinkan terjadi dalam mekanisme ini dapat diantisipasi dan diminimalisir sebagaimana dijelaskan sebelumnya. Sehingga mekanisme ini dapat berjalan sesuai dengan rencana.

4. Implikasi Pemberlakuan E-Voting dengan Electronic Voting Machine (EVM) dan Fingerprint One-Detect Verification (FOV) dalam Pelaksanaan Pemilu

a. E-Voting dengan EVM dan FOV Sebagai Katalisator Modernisasi dan Pembangunan Hukum di Indonesia

Mekanisme e-voting dengan EVM dan FOV yang memanfaatkan teknologi dalam pelaksanaan pemilu, sejalan dengan konsep modernisasi. Modernisasi dapat diartikan sebagai proses perubahan dari cara-cara tradisional ke cara-cara baru yang lebih maju. ${ }^{35}$ Secara konkret, cara pemilihan dalam pemilu yang saat ini dilakukan secara konvensional yaitu dengan mencoblos atau mencontreng di surat suara, mengalami perubahan menjadi e-voting dengan EVM dan FOV yang memanfaatkan teknologi yang berimplikasi kepada kemudahan, praktis, dan suatu langkah maju dalam menghadapi tantangan teknologi yang semakin berkembang pesat.

Upaya masyarakat untuk mengerahkan dan memasukkan unsur teknologi sebagai katalisator modernisasi dalam perwujudan proses demokrasi juga merupakan wujud dari suatu pembangunan hukum. Kini, mekanisme e-voting

33 Irso, "Dirjen PPI: Survei Penetrasi Pengguna Internet di Indonesia Bagian Penting dari Transformasi Digital", kominfo.go.id, https://www.kominfo.go.id/content/detail/30653/dirjenppi-survei-penetrasi-pengguna-internet-di-indonesia-bagian-penting-dari-transformasidigital/0/berita_satker, diakses pada tanggal 04 Maret 2021.

${ }^{34}$ Nugraha, Anggara Cahya, Hanggara, Buce Trias, dkk. (2020). Evaluasi dan Perbaikan Proses Bisnis Proyek Palapa Ring (PARING) Menggunakan Metode Business Process Improvement (BPI) (Studi Kasus: Badan Aksesibilitas Telekomunikasi dan Informasi), Jurnal Pengembangan Teknologi Informasi dan Ilmu Komputer, 4(3), 39.

${ }^{35}$ Abdulsyani. (1994). Sosiologi, Skematika, Teori, dan Terapan. Jakarta: Bumi Aksara, h. 176. 
mulai dikerahkan oleh masyarakat pemerintahan di desa atau kabupaten/kota, salah satunya ialah Kabupaten Jembrana, Bali. Kegiatan pemungutan suara pada kabupaten ini sudah sejak lama meninggalkan mekanisme konvensional. Tidak hanya Kabupaten Jembrana, di Indonesia ternyata telah terdapat 981 desa di 18 Kabupaten dan 11 Provinsi se-Indonesia yang telah menggunakan mekanisme $e$ voting untuk pilkades. ${ }^{36}$

Mengacu pada pendapat Emon Makarim, bahwa:

"Dari sisi functional equivalent approach, tindakan tersebut dapat dipersamakan dengan mencoblos sepanjang sistemnya handal, aman, dan bertanggung jawab. Jadi jika tujuan menyentuh layar monitor yang sudah didesain secara elektronik adalah sama dengan tujuan mencoblos, maka dengan sendirinya sepanjang akuntabilitas sistem terjaga, hal itu selayaknya dapat dipersamakan dengan mencoblos."37

Mengingat UUD NRI 1945 membuka celah bagi open legal policy terhadap pelaksanaan pemilu, maka harus ditafsirkan dengan pandangan adaptif terhadap perkembangan dan saripati kesiapan masyarakat untuk suatu perubahan. Secara tidak langsung, konstitusional Indonesia yang bersifat demokratis tidaklah mempermasalahkan mekanisme mana yang seharusnya dibawakan dalam pelaksanaan pemilu, melainkan memfokuskan diri terhadap proses apapun yang dipakai sejatinya harus tetap memegang teguh norma dalam asas-asas pemilu.

Selain itu, mekanisme ini sejalan dengan pemikiran Lawrence $M$. Friedman ${ }^{38}$, bahwa dengan adanya e-voting dengan EVM dan FOV akan memperkaya pelaksanaan sistem hukum melalui teknologi informasi dan komunikasi yang memanfaatkan internet sebagai suatu sarana terkhusus dalam aspirasi hak politik warga negara.

Mekanisme ini juga sejalan dengan Amanat Undang-Undang Nomor 17 Tahun 2007 tentang Rencana Pembangunan Jangka Panjang Nasional (RPJPN) 2005-2025, bahwa sasaran dalam pembangunan hukum sendiri adalah terwujudnya konsistensi seluruh peraturan perundangan-undangan baik tingkat pusat maupun daerah agar bermuara pada terciptanya hukum nasional yang adil. ${ }^{39}$ Pemberlakuan e-voting dengan EVM dan FOV mendorong penjaminan asas pemilu yang akan sejalan dengan pembangunan hukum Indonesia.

b. Meringankan beban kerja panitia ad hoc

Mekanisme e-voting dengan EVM dan FOV akan mengubah proses penghitungan serta pengecekan surat suara yang biasanya dilakukan oleh panitia ad hoc pemilu, menjadi otomatis karena terbantu kecanggihan teknologi.

\footnotetext{
36 Anwar Siswadi, "Saat Orang Kota Nyoblos Pakai Paku, 981 Desa Sudah E-Voting”, Tempo.co, berita dari https://tekno.tempo.co/read/1202782/saat-orang-kota-nyoblos-pakai-paku-981-desasudah-e-voting, diakses pada 15 Maret 2021.

37 Putusan Mahkamah Konstitusi Nomor: 147/PUU-VII/2009, h. 35.

38 Friedman, Lawrence M. (2001). Hukum Amerika: Sebuah Pengantar (American Law: An Introduction). Jakarta: PT. Tatanusa, h.7.

39 Saptomo, Ade., Marwan, Awaludin., dkk. (2019). Dokumen Pembangunan Hukum Nasional Tahun 2019. Jakarta: Badan Pembinaan Hukum Nasional (BPHN), h. 48.
} 
Hal ini akan mengurangi beban kerja dan mengurangi jumlah panitia ad hoc, sehingga beban kerja dengan upah kerja akan seimbang.

c. Mempermudah mobilisasi dan alokasi logistik pemilu

EVM dan FOV merupakan alat e-voting yang praktis sehingga mengakibatkan alokasi logistik hanya dilakukan di awal pemberlakuan dan kondisi tertentu saja. Hal ini akan mempermudah mobilisasi dan alokasi logistik pemilu dibandingkan dengan mekanisme sebelumnya yang membutuhkan alokasi berulang setiap diadakannya pemilu.

d. Menghemat anggaran yang dikeluarkan untuk jangka panjang

Dalam mekanisme ini, nantinya KPU hanya perlu menyediakan mesin atau alat yang mana mesin ini dapat digunakan secara berulang dan berlanjut. Sehingga, secara jangka panjang akan menghemat anggaran. Penulis telah mencoba membuat rasionalisasi kisaran anggaran pemilu mekanisme e-voting dengan EVM dan FOV.

\section{PENUTUP}

Sampai saat ini, pemilu di Indonesia diselenggarakan dengan mekanisme konvensional yakni dengan cara mencoblos atau mencontreng surat suara. Namun, mekanisme konvensional tersebut menimbulkan banyak permasalahan, yakni (1) beratnya beban kerja panitia ad hoc pemilu; (2) mobilitas dan alokasi logistik yang rumit; (3) alokasi anggaran Pemilu Serentak Indonesia 2019 yang relatif besar; dan (4) banyaknya surat suara tidak sah disebabkan tingkat pengetahuan masyarakat yang rendah. Dalam mekanisme e-voting yang penulis gagas, FOV merupakan tahap awal atau verifikasi sebelum memilih dengan EVM untuk menghindari multivoting. Hal tersebut karena mesin ini akan dilengkapi kemampuan untuk mendeteksi verification yang menyebabkan pemilih yang telah verifikasi tidak dapat memilih untuk kedua kalinya karena database telah terekam oleh sistem. Kemudian, verifikasi ini akan terekam kepada komputer penyelenggara yang nantinya akan diberikan kepada pusat. FOV ini dilengkapi dengan papan ketik nomor apabila terjadi kekeliruan atau pemilih belum memiliki e-KTP maka bisa menuliskan NIK untuk alternatif. Di sisi lain, potensi permasalahan yang mungkin timbul dari mekanisme e-voting dengan inovasi EVM dan FOV ini adalah (1) permasalahan perlindungan data pribadi, praktik hack, dan kecurangan; (2) permasalahan error; dan (3) permasalahan internet. Solusi yang penulis tawarkan untuk mengatasi potensi permasalahan tersebut adalah (1) membentuk komisi khusus yang memastikan penyelenggara data pribadi tunduk terhadap RUU PDP, mengadopsi perangkat lunak sekaligus sistem keamanan e-voting di India, dan mengadopsi sistem keamanan e-voting di Brazil; (2) melengkapi FOV dengan papan numerik sehingga dapat dilakukan verifikasi dengan NIK dan memberikan pelatihan pada ahli TI atau teknisi; serta (3) mendorong pemerintah untuk segera merampungkan program Palapa Ring dan menyediakan cadangan kuota data internet. Implikasi dari pemberlakuan mekanisme ini akan memberikan manfaat seperti (1) meringankan beban kerja panitia ad hoc; (2) mempermudah mobilisasi dan alokasi logistik pemilu; (3) 
menghemat anggaran yang dikeluarkan untuk jangka panjang; dan (4) meminimalisir surat suara tidak sah.

Akhir kata, mekanisme yang penulis gagas tentunya masih menjadi bahan pembelajaran dan pembenahan yang perlu dilakukan oleh berbagai pihak terkait. Penulis menyarankan pemerintah serta pihak terkait untuk mempertimbangkan mekanisme ini atau dapat mengambil kebaikan dari inovasi, teknologi, maupun manfaat dari mekanisme yang penulis rancang untuk pelaksanaan Pemilu Indonesia 2029. Kemudian, untuk menyempurnakan mekanisme ini, selayaknya untuk melakukan Revisi UU Pemilu mengenai pembentukan "Tim Revolusi E-Voting" dan teknis pelaksanaannya dan Peraturan KPU yang menjabarkan teknis pelaksanaan lebih lanjut e-voting dengan EVM dan FOV di Indonesia. Selain itu, sosialisasi mengenai mekanisme ini merupakan hal yang penting untuk meningkatkan pengetahuan dan pemahaman penyelenggara, pihak terkait, maupun masyarakat luas mengenai mekanisme yang penulis rancang.

\section{DAFTAR PUSTAKA}

Abdulsyani. (1994). Sosiologi, Skematika, Teori, dan Terapan. Jakarta: Bumi Aksara.

Afrimadona, Amir Nashirudin, dkk. (2019). Perihal Pemungutan dan Penghitungan Suara, cet. ke-1, Jakarta: BAWASLU.

Blanc, Jarrett. (2007). Challenging the Norms and Standards of Election Administration. USAID (hal 11-19). IFES.

Friedman, Lawrence M. (2001). Hukum Amerika: Sebuah Pengantar (American Law: An Introduction), Jakarta: PT. Tatanusa.

Habibi, Muhammad dan Nurmandi, Achmad. (2019). “Dinamika Implementasi E-Voting di Berbagai Negara". Jurnal UMY, 7(2), 4.

KPU Kab. Sleman. (2019). Laporan Pembentukan Badan Penyelenggara Ad Hoc Pemilu 2019 Kabupaten Sleman. Sleman: KPU.

Mote, C.D. (2001). Report of the National Workshop on Internet Voting-Issues and Research Agenda. Internet Policy Institute.

Nugraha, Anggara Cahya, Hanggara, Buce Trias, dkk. (2020). “Evaluasi dan Perbaikan Proses Bisnis Proyek Palapa Ring (PARING) Menggunakan Metode Business Process Improvement (BPI) (Studi Kasus: Badan Aksesibilitas Telekomunikasi dan Informasi)". Jurnal Pengembangan Teknologi Informasi dan Ilmu Komputer, 4(3), 39.

Rahardjo, Satjipto. (2006). Membedah Hukum Progresif. Jakarta: Kompas.

Reddy, A.K. (2011). “A Case Study On Indian E.V.M.S Using Biometrics”. International Journal Of Engineering Science \& Advanced Technology, 1(1), 40-42.

Rosadi, Farida., Reni Saptati, dkk. (2019). Media Keuangan: Transparansi Informasi Kebijakan Fiskal, Vol. XIV/No.139/April 2019. Jakarta: Sekretariat Jenderal Kementerian Keuangan.

Saptomo, Ade., Marwan, Awaludin., dkk. (2019). Dokumen Pembangunan Hukum Nasional Tahun 2019. Jakarta: Badan Pembinaan Hukum Nasional (BPHN).

Satriawan, Iwan dan Lailam, Tanto. (2019). “Open Legal Policy dalam Putusan Mahkamah Konstitusi dan Pembentukan Undang-Undang”. Jurnal Konstitusi, 16 (3), 564. 